\title{
Knowledge, attitude and practice of HIV/AIDS among employees of a medical line factory in Kamunting, Malaysia
}

\author{
Navinder Kaur, Nik Ahmad Izani, Vivekanandan Gopalakrishnan* \\ From 2nd International Science Symposium on HIV and Infectious Diseases (HIV SCIENCE 2014) \\ Chennai, India. 30 January - 1 February 2014
}

\section{Background}

Adults aged between 20 and 39 years constituted for more than half of the new HIV cases in Malaysia. Even though there was a high level of awareness regarding HIV/AIDS among the Malaysian public, there were still misconceptions.

\section{Methods}

It is a cross sectional study conducted at the Latex Manufacturing Sdn.Bhd. Questionnaire was distributed to employees, questions in regard to demographic profiling, knowledge, attitude and practice related to HIV/AIDS were included.

\section{Results}

The study population $(\mathrm{n}=314)$ showed knowledge level with median score of $13 / 16$. However, $46.8 \%$ of them could not differentiate between HIV and AIDS, 30.9\% believed HIV was transmittable by mosquito bites, 30.6\% believed condom usage would not lower HIV risk and $39.5 \%$ believed showering or washing genitals after sexual intercourse could lower the risk. Respondents showed good attitude towards people with HIV/AIDS with median attitude score of 5/6. Higher level of education showed higher knowledge level and better $(p<0.05)$. About 29\% did not use condom during sexual intercourse. Twenty percent had multiple partners and $8 \%$ did not use condom regularly with their multiple partners. Twenty seven $(8.6 \%)$ of male respondents had sexual relationship with other men. About $10 \%$ of them were willing to have blood transfusions with blood products of unknown HIV status.

* Correspondence: gopalakrishnan@rcmp.unikl.edu.my UNIKL RCMP, 3 Jalan Greentown, Ipoh, Malaysia
High knowledge level did not show better practices related to HIV/AIDS.

\section{Conclusion}

Employees had modest knowledge in regard to HIV/AIDS. Nevertheless, misconceptions and stigmatization in regard to the illness was present, showing that their understanding and concept about the infection was still not satisfactory.

Published: 27 May 2014

doi:10.1186/1471-2334-14-S3-P82

Cite this article as: Kaur et al:: Knowledge, attitude and practice of HIV/AIDS among employees of a medical line factory in Kamunting, Malaysia. BMC Infectious Diseases 2014 14(Suppl 3):P82.
Submit your next manuscript to BioMed Central and take full advantage of:

- Convenient online submission

- Thorough peer review

- No space constraints or color figure charges

- Immediate publication on acceptance

- Inclusion in PubMed, CAS, Scopus and Google Scholar

- Research which is freely available for redistribution
() Bïomed Central 